\title{
Student Loans in Comparative and International Perspective
}

\section{Richard Hopper}

Richard Hopper is on the staff of the World Bank, $1818 \mathrm{H}$ St. NW, Washington, DC. 20433, USA. E-mail: <rhopper@worldbank.org>.

$\mathrm{I}^{\mathrm{n}}$ n higher education systems across the world, the trend toward increased cost sharing in public universities and the growth of private institutions have led to the creation of many ways to assist students in paying ever more of their own education and related expenses. These modes of assistance fall into two categories: grants and loans-though it could be argued that service agreements, in which a student's education expenses are paid in return for work or public or military service, constitute a third major category of aid. Both grant and loan programs draw support from a variety of sources- public, private, nonprofit, and nongovernmental. Grants are essentially gifts, whether to help the brightest, the poorest, the most interesting, the most enterprising, the most well-connected, or simply the luckiest students. Student loans, however, are not as easy to characterize. Depending on the terms, a loan may resemble a grant or may actually increase the cost of higher education over time. Inflation and other unpredictable economic vagaries can also contribute to that outcome. The institutions that capitalize and administer student loans can do so out of benevolence or out of a desire to turn a profit. While student loans can be an effective equity tool to help students who otherwise could not afford higher education, their cost and difficulty of procurement may negate any equity effect. Student loans seem to defy straightforward analysis.

Student loans as an instrument of financial aid are all the more curious when we consider the findings of research on student loans and the practice of lending. The literature tells us that-especially in developing coun- tries or in times of high inflation-student loans are not always an efficient or even a practical way to assist students in gaining access to and paying for their education.

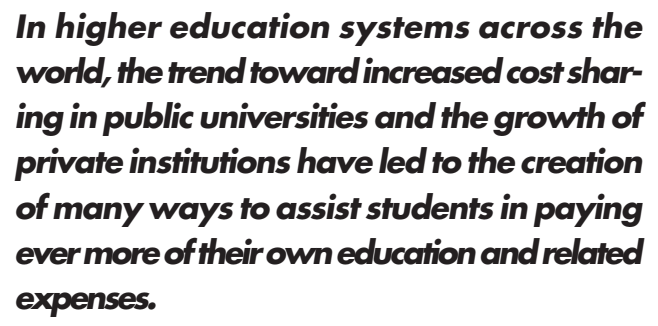

Administration of student loans is often said to be complicated and expensive, while student tracking and repayment can often be difficult or impossible to ensure. Indeed, the literature cites program cost and student default to be the top reasons for program failure. Nevertheless, student loan programs continue to proliferate with each program attempting to beat the odds. What is so appealing about student loan programs? Is it the notion of student self-help or the idea that lending institutions might be able to save or even make money from such an enterprise? Whatever the reasons, student loan programs continue to be a growing presence in higher education the world over. It is for this reason that we hope to capture some of our information about student loan programs. We hope that these short contributions will stimulate discussion and analysis so that we can refine our understanding of student loans- their role, advantages, drawbacks, and general character.

\section{Student Loans: The World Bank Experience}

\begin{abstract}
Jamil Salmi
Jamil Salmi is education sector manager, Latin American and the Caribbean Region, World Bank. Address: The World Bank, 1818 H St. NW, Washington, DC 20433, USA. The findings, interpretations, and conclusions expressed in this paper are entirely those of the author and should not be attributed in any manner to the World Bank, the members of its Board of Executive Directors, or the countries they represent.
\end{abstract}

\section{An International Perspective}

Student loan schemes exist in more than 60 countries, Onaking them an increasingly important financing mechanism for higher education. Traditionally, public agencies have run student loan programs, but in recent years new loan agents have appeared: commercial banks, for-profit private agencies, and nonprofit institutions. Many schemes are national in scope, but in the State of Sonora a very effective public agency has operated since 1981. In Brazil, in the State of Rio Grande do Sul, a group of alumni created a successful student loan foundation in the 1970s (FUNDAPLUB). Student loan institutions (SLIs) worldwide are funded by the following sources: governments, students, firms, alumni, and international agencies. In addition to the repayments by beneficiaries and income generated through their own financial investments, public agencies often receive additional funding through budgetary contributions, either from the national government or 